\title{
MORPHOLOGICAL PATTERNS OF CREVICE-TYPE CAVES IN SEDIMENTARY ROCKS OF THE OUTER WESTERN CARPATHIANS (CZECH REPUBLIC)
}

\author{
JAN LENART ${ }^{1}$ \\ ${ }^{1}$ Department of Physical Geography and Geoecology, Faculty of Science, University of Ostrava, Chittussiho 10, 71000 Ostrava, \\ Czech Republic, jan.lenart@osu.cz
}

\begin{abstract}
I evaluate crevice-type caves in the Outer Western Carpathians from the morphological point of view at different scales, from the overall arrangement of cave passages within the massif, to their shape and finally to the micro-morphological features of their walls and ceilings, using examples from the Czech part of the Carpathians. The cave passages are typically parallel to and follow the strike of the slope, but the passages of relatively large caves are typically fan-like arranged. Vertically, the passages are organized at particular levels governed by lithology. They can be staircase-shifted with each other. The gradual opening of the uppermost level may lead to deformation of the surface terrain, however, this terrain can be entirely flat, which gives evidence of the gravitational widening of the caves from the inside of the massif. In cross-section, the passages are A, V, or $\mathrm{H}$ letter shaped, according to the type of gravitational movement leading to their development. The various micromorphological features that originate from sedimentology, tectonics, gravitational processes, and mechanical and chemical weathering sometimes mark the exposed walls and ceilings.
\end{abstract}

\section{INTRODUCTION}

Crevice-type caves (CTCs) are one of many types of pseudokarst caves (Bella and Gaál, 2013). They were defined for the first time by Vítek (1983). These caves are formed during the evolution of slope deformations and consist of a system of accessible gravitationally widened joints that form the cave passages. It means that these caves are formed as products of gravitational processes without any role of karstification during their evolution. For comparison, Gutiérrez et al. (2014) summarizes the role of the karst processes before and during the dilation and propagation of joints and clefts in soluble rocks.

The development of the caves is described and widely discussed in Margielewski and Urban (2003), Pánek et al. (2010) and Lenart et al. (2014). CTCs occur in various rock types, such as clastic rocks (Winkelhöfer, 1975; Vítek, 1983; Wagner et al., 1990; Pánek et al., 2010; Lenart et al., 2014), limestones (Pánek et al., 2009), chalk (Rodet, 1983), basalts (Gaál and Gaál, 1995), granites (Finlayson, 1986), gneisses (Demek and Kopecký, 1999), and others. Although CTCs occur worldwide, there is a lack of investigations evaluating the morphology of these caves. The caves commonly accompany landslides of various types: topples, translational, and rotational slides and lateral spreads (according to Varnes, 1978), both deep-seated (according to Hutchinson, 1988) and shallow (according to Margielewski, 2009) types.

CTCs are very often developed in incoherent sedimentary flysch deposits, e.g., in sandstones and conglomerates with intercalations of shales such as siltstones and claystones
(Wagner et al., 1990; Margielewski and Urban, 2003; Urban and Margielewski, 2013; Lenart et al., 2014).

This paper evaluates and reviews CTCs from the morphological point of view, based on examples from the flysch belt of the Czech portion of the Western Flysch Carpathians (Fig. 1). I extend the investigations of Margielewski and Urban (2003), Pánek et al. (2010), Urban and Margielewski (2013), and Lenart et al. (2014). I analyze morphological peculiarities of CTCs within gravitationally affected flysch slopes. Using the detailed morphological and structural data from CTCs in the Czech section of the Outer Flysch Carpathians, this study aims to describe and evaluate morphological features and patterns of CTCs at four different scales: (i) overall horizontal arrangement of the passages, (ii) overall vertical arrangement of the passages, (iii) morphology of the particular passages, and (iv) micromorphology of the walls and ceilings of the caves.

\section{Study Area}

Crevice-type caves were investigated in the Czech portion of the Outer Flysch Carpathians (Fig. 1), which is strongly affected by mass movements of various types. The study area has local relief up to $600 \mathrm{~m}$ and is affected by numerous deep-seated gravitational slope deformations, mainly by structurally predisposed translational and rotational landslides (Krejčí et al., 2004; Pánek et al., 2011). The Moravskoslezské Beskydy mountains (highest peak Lysá hora, $1323 \mathrm{~m}$ a.s.l.) and the Javorníky mountains (Velký Javorník: $1071 \mathrm{~m}$ a.s.l.) are the most distinct geomorphic units of that area.

Journal of Cave and Karst Studies, December 2015 • 165 

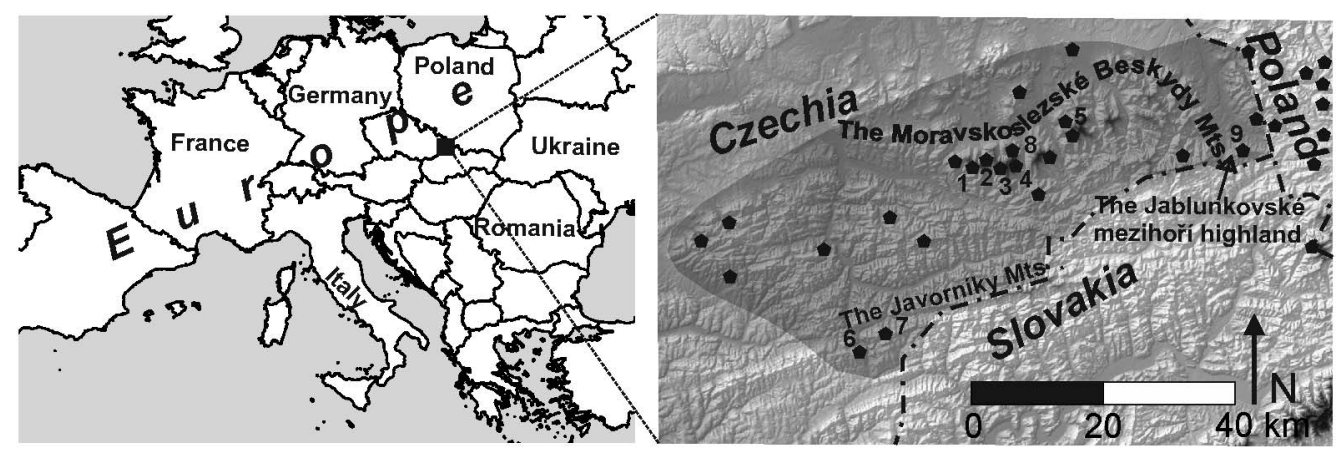

\begin{tabular}{|l|c|c|c|c|}
\hline CTCs & overall & small & medium & long \\
\hline count & 109 & 92 & 11 & 6 \\
\hline percentage & 100 & 84 & 10 & 6 \\
\hline
\end{tabular}

\begin{tabular}{|l|c|c|c|c|}
\hline \multicolumn{4}{|c|}{ distribution of the crevice-type caves } & \\
\hline CTCS & overall & small & medium & long \\
\hline identified caves & 56 & 41 & 9 & 6 \\
\hline parallel & 44 & 31 & 7 & 6 \\
\hline$\%$ of parallel & 78 & 76 & 78 & 100 \\
\hline non-parallel & 12 & 10 & 2 & 0 \\
\hline$\%$ of non-parallel & 22 & 24 & 22 & 0 \\
\hline not identified & 53 & 51 & 2 & 0 \\
\hline
\end{tabular}

Figure 1. Studied area in the Czech section of Outer Flysch Carpathians (shaded). Black dots indicate places with crevice-type cave occurrence, with the longest and the deepest caves labeled: 1, Salajka Cave; 2, Cyrilka Cave; 3, Čertova Díra Cave; 4 , Kněhyňská Jeskyně Cave; 5, Velká Ondrášova Jeskyně Cave; 6, Naděje Cave. Other caves mentioned in the text: 7, Velryba Cave; 8, Kyklop Cave; 9, Na Girové I Cave. Tables give total number of caves in each size category and numbers and percentages of caves arranged parallel and non-parallel to the strike of the slope.

The Outer Flysch Carpathians are composed primarily of Mesozoic (Late Jurassic) to Paleogene/Neogene (early Miocene) rocks. Several nappes were folded and thrusted onto the foredeep in a northerly direction during the lower and middle Miocene alpine phases. The strata predominantly consist of thick-bedded, medium-grained sandstones or coarse-grained sandstones to conglomerates with content of mica, glauconite, and calcareous cement, frequently interrupted by thin-bedded intercalations of shales, such as claystones and siltstones, with a predominant illite and kaolinite content. During the Miocene, the flysch massif was strongly disrupted by joints and faults trending in several directions (E-W, N-S, NW-SE, NE-SW and WNW-ESE). The most important is the NW-SE direction, which corresponds to the direction of regional faults. All geological characteristics are taken from Menčík et al. (1983), Pánek and Duras (2002), Krejčí et al. (2002), Margielewski and Urban (2003), Krejčí et al. (2004), and Pánek et al. (2011).

Mountain ridges typically are monoclinal ridges and cuestas, structural ridges formed by more resistant strata, and anticlinal and synclinal ridges. The northern slopes are often steep and correspond to the frontal parts of beds, whereas the southern slopes are long and gentle, following the dip, ranging from SW to SE, of the bedding planes (e.g., Menčík et al., 1983; Krejčí et al., 2004).

CTCs are considered as important geomorphic elements of gravitationally deformed slopes. To date, more than one hundred CTCs are known in the study area. Figure 1 shows the distribution of the most remarkable examples localized in the outer part of the Czech Flysch Carpathians. The majority of the 109 investigated CTCs (84\%) are categorized as small caves up to $30 \mathrm{~m}$ in length, and $10 \%$ are categorized as medium caves, with length between 30 and $100 \mathrm{~m}$ and up to $30 \mathrm{~m}$ in depth. The remaining part $(6 \%)$ is represented by long caves, longer than $100 \mathrm{~m}$ or deeper than 30 $\mathrm{m}$. The longest one, the Cyrilka Cave, reaches $535 \mathrm{~m}$ and the deepest is the Kněhyňská jeskyně, with the bottom at $57.5 \mathrm{~m}$ of depth (Wagner et al., 1990).

\section{Methods}

To study the overall horizontal arrangement of the passages, I used the older maps of crevice-type caves published mostly by Wagner et al. (1990). These maps were updated and revised using a DISTO Leica A3 laser rangefinder improved with a DistoX component (Heeb, 2008). Maps were compared with surface topography that was measured to high precision with a geodetic total station (Lenart et al., 2014). Overall, the vertical arrangements of the passages were identified on the basis of cave cross-sections. The morphological character of each particular passage was determined on the basis of its detailed cross-sections combined with the dip directions of walls and ceilings. In terms of the strike characteristics of the sedimentary beds, the joints and faults were classified as L (longitudinal), $\mathrm{T}$ (transversal), and D1+D2 (two diagonal systems), a classification according to Mastella et al., 1997, based on the relation between the dip direction of rock layer and the direction of joint set. The detailed micro-morphological features were observed directly. 


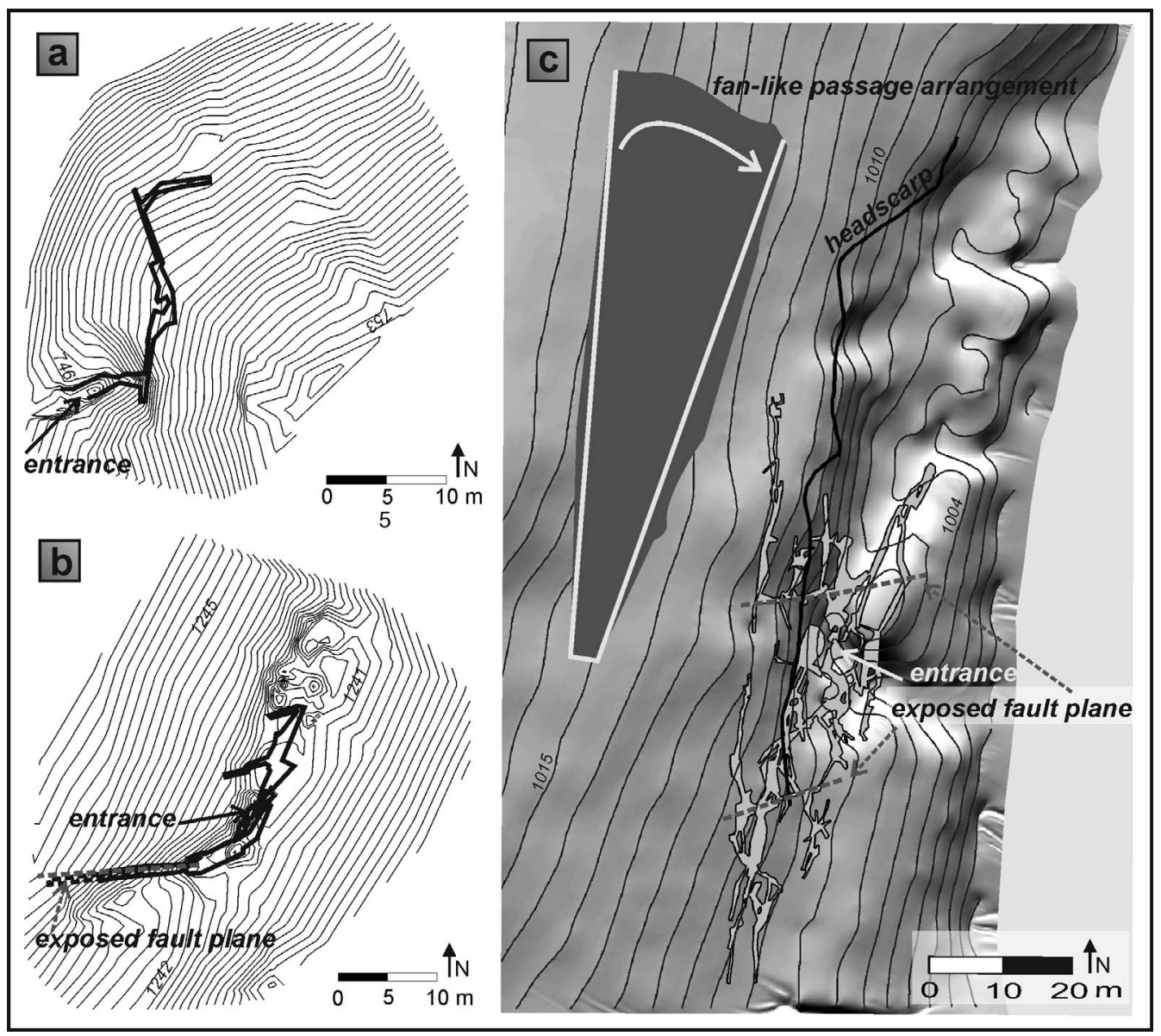

Figure 2. Examples of different arrangement of the passages in crevice-type caves with or without surface manifestations: a. CTC formed by passages that follow the strike of the slope. Note the limited topographical manifestation (Velryba Cave, the Javorníky Mts.). b. CTC with secondary passages diagonally or transversally oriented toward the main passage. Note the strong correlation with topography (Kyklop Cave, the Moravskoslezské Beskydy Mts.). c. Complicated CTC with fan-like arrangement of the passages due to the laterally uneven gravitational movement of rock blocks. Some parts do not correlate with the surface features (Cyrilka Cave, the Moravskoslezské Beskydy Mts.).

\section{MORPHOLOGY}

\section{Horizontal Arrangement of Cave Passages}

Crevice-type caves consist of a system of narrow and mutually parallel accessible crevices formed by gravitationally widened joints, the orientation of which is the most important feature controlling the direction of individual cave passages. In many cases, the small CTCs, up to $30 \mathrm{~m}$ in length, are formed by several accessible crevices that follow the strike of the slope (Fig. 2a). In the case of the medium-length CTCs, the main passages follow the strike of the slope and connecting passages are diagonal or transverse to them (Fig. 2b), according to the directions of joint sets. In some cases, these secondary passages follow the strike-slip fault planes (Figs. 2b and 3a). The long caves are formed by a system of mutually parallel passages along the strike of the slope that are connected by diagonal and transverse passages developed along the strike-slip faults or within the highly disrupted rock blocks (Fig. 2c). Figure 1 shows the numbers and percentages of identified caves with passages arranged generally parallel to the strike of the slope in each category.

The passages of the caves with lengths of more than approximately one hundred meters are typically fan-like arranged (Fig. 2c). This can result, first, due to an intersection of joint sets in two or more main directions (Fig. 3d) or, second, from the laterally uneven gravitational movement of rock blocks (Fig. 2c), so that each side of the fan moved differently and one side is now opened more than the other. In the first case, the largest cave rooms and passages are formed in and around the point of intersection of the main directions of joint sets (Fig. 3d). These passages are usually the most dissected and disturbed. In the second case, the widest cave passages are formed in the area of the largest opening of the fan (Fig. 2c), and these passages often pass into a talus or boulder cave (after Vítek, 1983). 

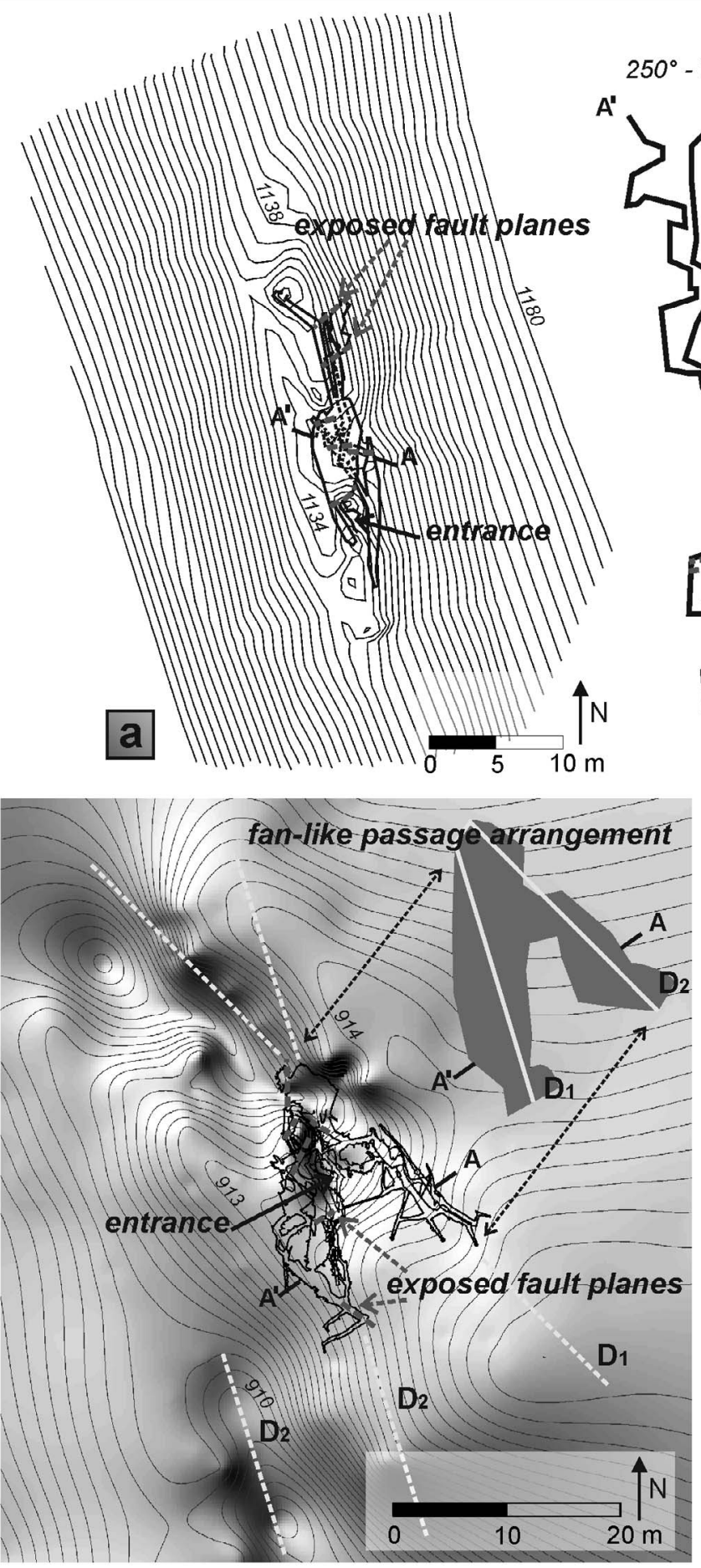

$250^{\circ}-70^{\circ}$
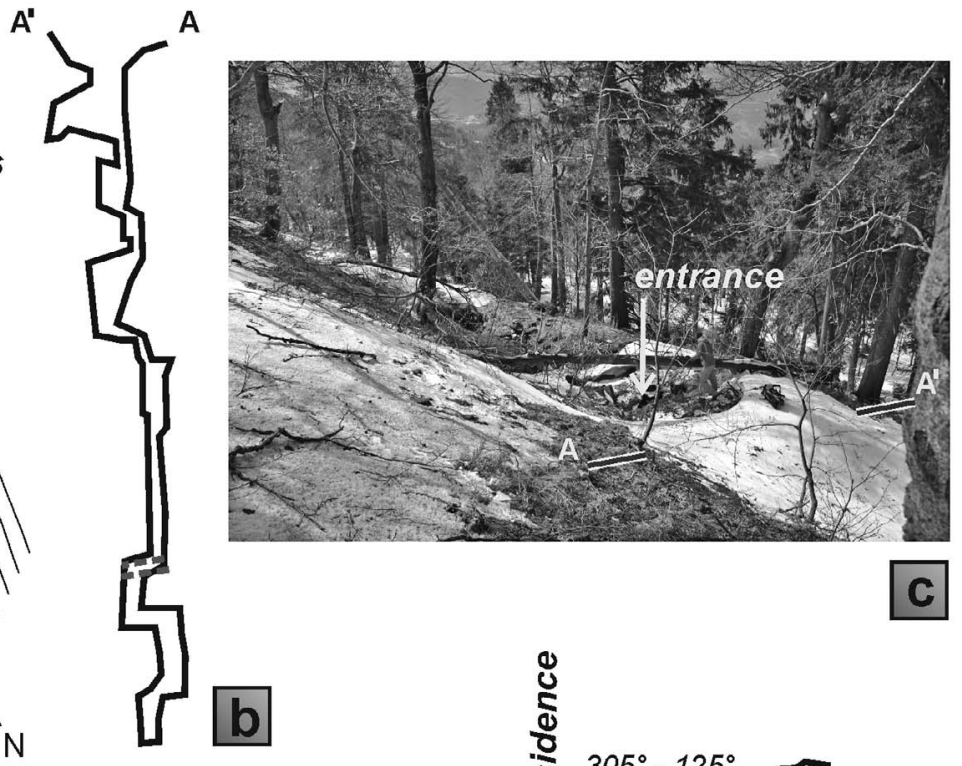

c

过

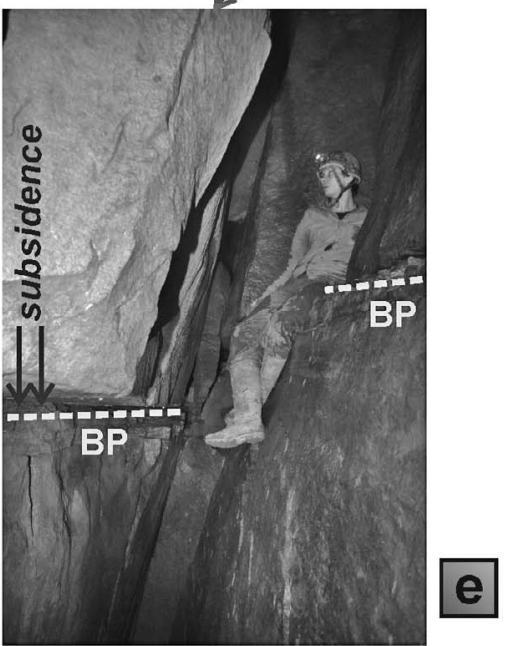

Figure 3. Examples of different horizontal and vertical arrangements of the passages. a. crevice-type cave with strong surface manifestations is developed along the faults passing through the massif (Črtova Díra Cave, the Moravskoslezské Beskydy Mts.). b. The cross-section of the same cave. The lowermost passages are terminated as inaccessible joints, and the vast chambers are in the upper levels. c. Surface trench connected with the development of the Čertova Díra Cave in parts a. and b.; photo by the author. d. Fan-like arrangement of passages in a complex multilevel cave due to an intersection of two main sets of joints (Velká Ondrášova Cave, the Moravskoslezské Beskydy Mts.). A-A', the location of the cross-section in part f.; D 1 and D2, the orientation of the joint sets. e. The subsidence of rock blocks within the lower level of the same cave; BP bedding plane. Photo by the author. f. Idealized cross-section of the Velká Ondrášova Jeskyně Cave in parts d. and e. The inner rock blocks are the most subsided. The dashed arrows connect the disrupted bedding planes. 
These parts are often disrupted by collapses, and the walls and ceilings are mostly crushed. The directions of joint sets here do not correlate with the prevalent directions measured elsewhere, and the arrangement of the passages is rather chaotic. Toward the tip of the fan, the passages become more compact, undisturbed, and narrow (Fig. 2c). In the study area, five out of the six long caves have fan-like passage arrangement.

\section{VERTICAL ARRANGEMENT OF CAVE PASSAGES}

Generally, $96 \%$ of all investigated crevice-type caves reach the maximum depth of $16 \mathrm{~m}$, and only four caves are from 30 to $57 \mathrm{~m}$ deep. At the cross-section perpendicular to the strike of the slope, the CTCs are composed of narrow and high passages, which may form levels that are connected together by pits elongated in the direction of the main joint set or by narrow openings. The vertical extent of levels is governed by the bedding planes. However, in the case of strictly vertically developed caves, there are only pseudo-levels formed by boulders and debris wedged between the walls.

Due to the lithological conditions within the massif, the levels typically can be staircase-shifted relative to each other. Generally, the lowermost passages are very narrow $(\sim 0.1 \mathrm{~m})$ and are terminated by inaccessible joints (Fig. $3 b)$. Conversely, in the upper levels, the passages are much wider $(\sim 1 \mathrm{~m})$, are regularly shaped, accessible, and, in some places, widened into spacious rooms (Figs. $3 \mathrm{~b}$ and $4 d)$. The ceilings are commonly formed from the lower bedding planes. The uppermost levels are formed between the particular disrupted and horizontally or vertically rotated rock blocks (Fig. 4f). These levels are often affected by rock collapses, and the ceilings are formed from the wedged boulders or disturbed rock debris, with small openings between particular blocks.

All fifteen medium and long caves have upper level passages wider than the lower levels. In some cases, the progressive opening of the uppermost levels leads to the deformation of the ground surface and to the formation of surface trenches, sinkholes, or collapsed pits (Fig. 3a,c). However, the terrain above ten out of the fifteen medium and long caves is undisturbed and flat (Fig. 2a). This is evidence of the development of widening of the caves gradually increasing from depth to the surface.

There are two caves with huge floating inner rock blocks in the study area. In the large cave systems (length $100 \mathrm{~m}$ or depth $10 \mathrm{~m}$ ) the staircase arrangement of levels is disorganized by huge floating inner rock blocks $\left(\sim 10 \mathrm{~m}^{3}\right)$, which sag 0.1 to $1 \mathrm{~m}$ into the widened underground space (Fig. 3e,f). During this vertical subsidence, these blocks were horizontally and vertically rotated. These blocks are usually situated within the cave systems, but even can reach the ground surface.

\section{Morphology of the Particular Cave Passages}

The individual passages are the gravitationally widened joints, the accessible crevices. They are regularly shaped and high $(\sim 0.5$ to $15 \mathrm{~m})$ but relatively narrow $(\sim 0.5$ to $1 \mathrm{~m}$ ). Their main directions commonly follow the strike of the slope, while a few passages follow different joint systems.

In cross-section, the passages are $\mathrm{A}, \mathrm{V}$, or $\mathrm{H}$ shaped, according to the type of gravitational movement that leads to their development (Figs. 4a,b,c). Their bottoms are covered by a mixture of mud, sand, and debris or by larger collapsed rock blocks. The walls are straight, flat, inclined $70^{\circ}$ to $90^{\circ}$, and are formed by a single rock bed or by a sequence of thinner beds with exposed bedding planes (Fig. 4d). Rarely, the passages are curved, probably following en echelon joints; an example is the $5 \mathrm{~m}$ long curved passage in Salajka Cave.

The ceilings are formed by the lower bedding planes of the overlying beds, which can be flat or jointed (Fig. 4e), or by wedged boulders with narrow intervening openings (Fig. 4f). There are usually very thin $(\sim 1.0 \mathrm{~cm})$ plastic layers of siltstones or claystones observable between the overhead bedding plane and the wall, separating the sandstone beds (Fig. 4e).

\section{Micro-Morphology of the Walls and Ceilings}

The rock surfaces within the caves sometimes expose micro-morphological features that originate from the depositional stage, tectonics, and secondary processes of gravity and weathering.

The sandstone beds are preserved as graded bedding with Bouma sequences, and occasionally with thin layers of fossilized plant detritus. The ceilings of the passages are often formed by exposed lower bedding planes, which can be shaped by load (groove) casts (Fig. 5a), flute marks (Fig. 5b), burrows, or markings. The oval depressions found in Cyrilka Cave on the upper bedding plane are probably tool marks (Fig. 6f).

The cave walls are formed by the joint surfaces. Their shape is controlled by the tectonics. The rose diagram in Figure $4 \mathrm{~g}$ shows the directions of 4557 joints measured in the caves, combined with the directions of faults (arrows).

Fault tectonics can cause the gradual opening of joints perpendicular to the strike-slip faults and parallel to the normal faults. In several caves, some of the fault surfaces are now exposed on the walls (Fig. 5c). These surfaces are covered by slickensides (dip $\sim 0^{\circ}$ to $15^{\circ}$ or $80^{\circ}$ to $90^{\circ}$; Fig. $5 \mathrm{c}, \mathrm{d}$ ). In the faults, the slickenfibers and slickolites can occur on the exposed walls (Fig. 5d,g). High pressure within the fault zone can cause the formation of tectonic breccia (Fig. 5f) and mylonitic quartz (Fig. 5e). The sense of tectonic strains is expressed by hackle marks on the exposed walls (Fig. 5h). The small-scale pinnate structures, which indicate the shear sense, might be visible on rock blocks subjected to extreme compression (Fig. 5j). Rarely, the plumose structures are preserved on the joint planes (Fig. 5i).

Journal of Cave and Karst Studies, December 2015 • 169 


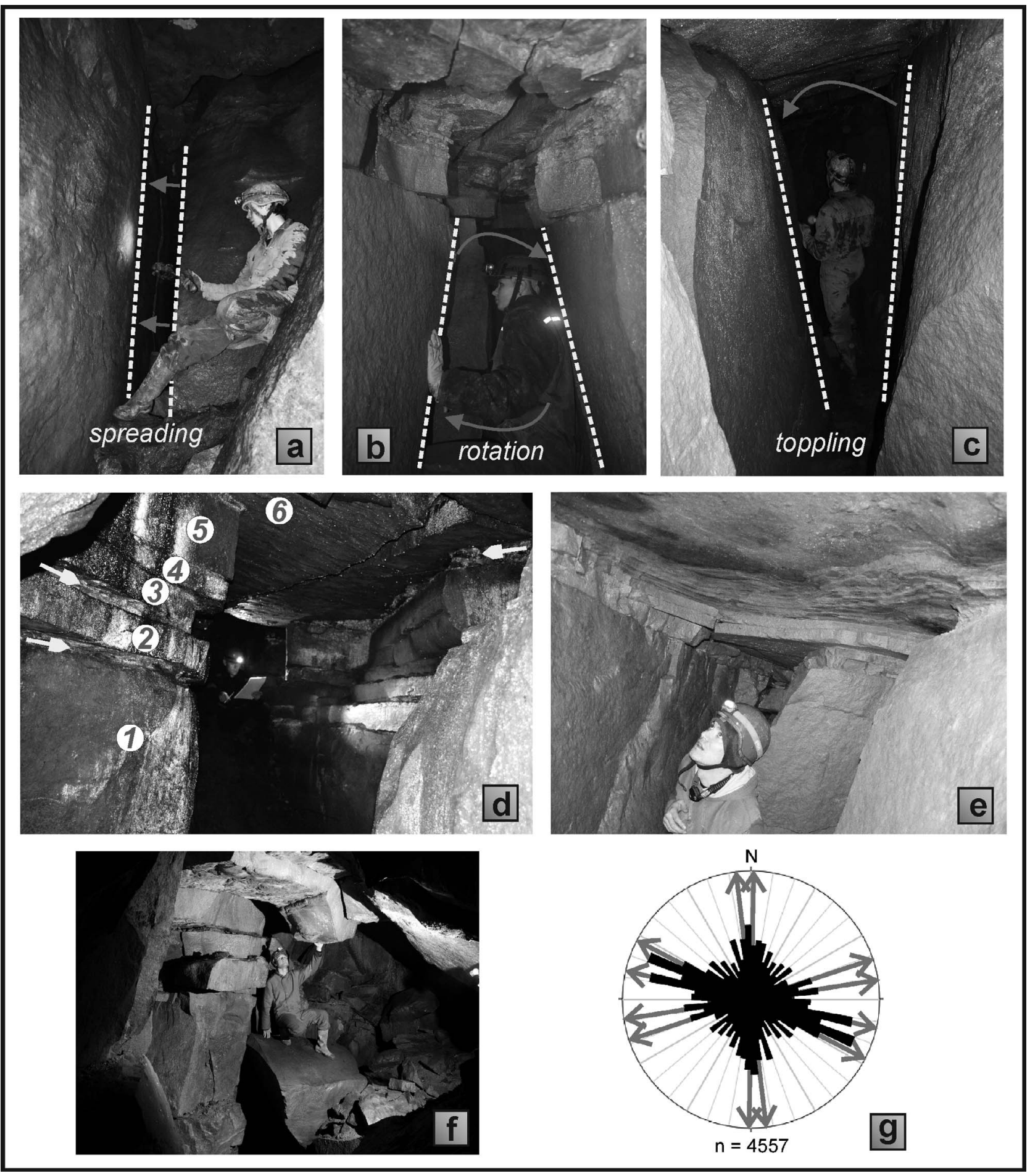

Figure 4. Morphology of the cave passages: a. H letter shaped passage caused by spreading-type movement (Velká Ondrášova Cave, the Moravskoslezské Beskydy Mts.). b. A letter shaped passage caused by rotational movement (Salajka Cave, the Moravskoslezské Beskydy Mts.). c. V letter shaped passage caused by toppling (Cyrilka Cave, the Moravskoslezské Beskydy Mts.). d. An example of typical walls formed by the exposed thick sandstone beds (numbers) and thin siltstone or claystone layers (arrows) Črtova Díra Cave, the Moravskoslezské Beskydy Mts.). e. Exposed flat ceiling formed by the base of a bed in Cyrilka Cave (the Moravskoslezské Beskydy Mts.) with plastic layers of siltstones or claystones between the overhead bedding plane and the wall. f. A ceiling formed by wedged boulders. Note the morphology of the walls shaped by the sandstone beds (the upper level in Kněhyňská Cave, the Moravskoslezské Beskydy Mts.). g. Rose diagram of 4557 measurements of joints within the caves, with arrows indicating the directions of faults taken from the geological maps. 

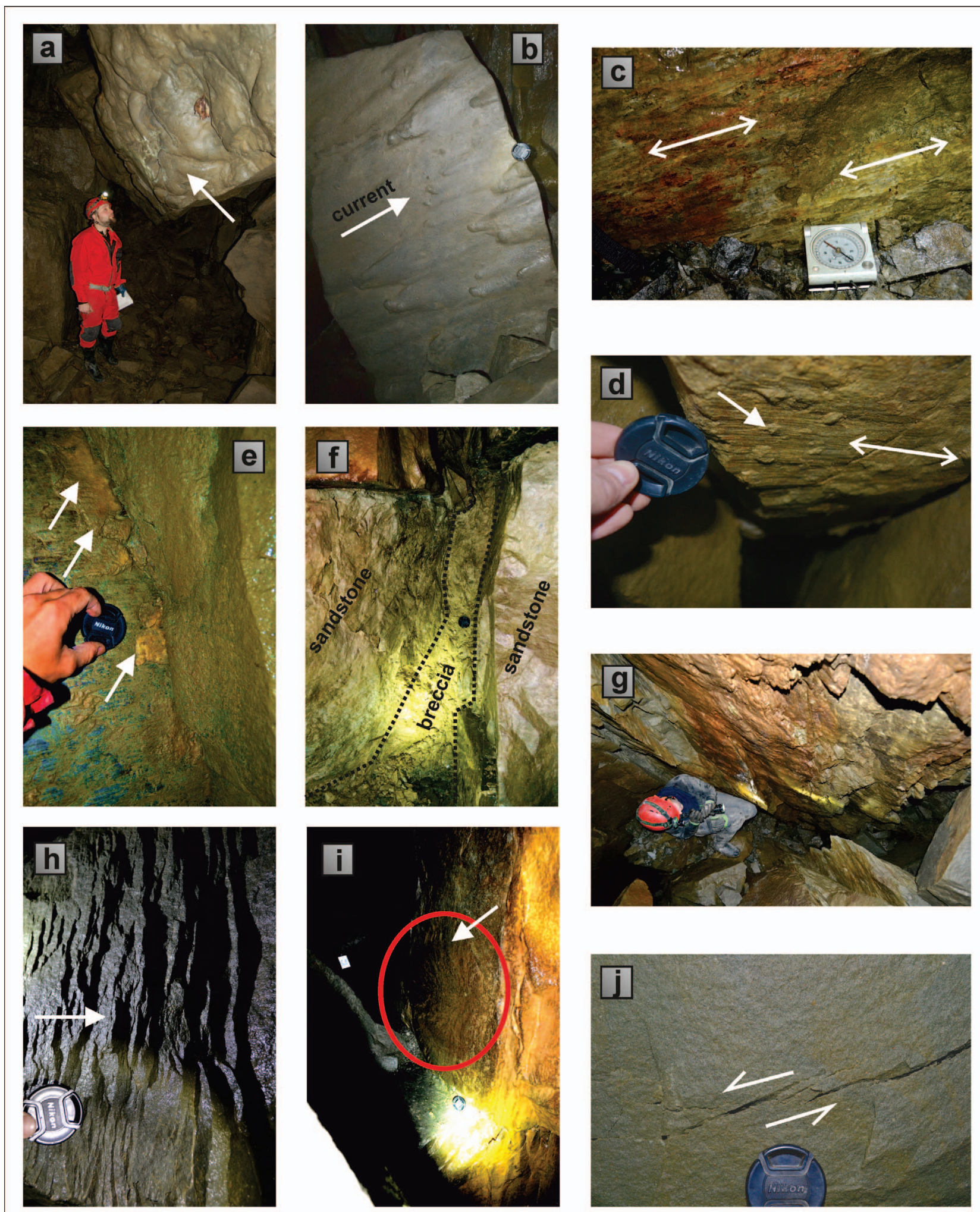

Figure 5. Micro-morphology of walls and ceilings of some crevice-type caves: a. Load casts. b. Flute marks; white arrow shows the current direction. c. Fault surface with marked direction of slickensides. d. Slickensides (direction indicated by double arrow) with slickenfibers (simple arrow). e. Mylonitic quartzite. f. Tectonic breccia infilling a crack, g. Slickolites. h. Hackle marks. i. Plumose structure with ripple marks (white arrow). j. Pinnate fractures indicating shear stress. a. Velká Ondrášova Cave (the Moravskoslezské Beskydy Mts.). b,. f., g., h., i., j. Kněhyňská Cave (the Moravskoslezské Beskydy Mts.). c., e. Čertova Díra Cave (the Moravskoslezské Beskydy Mts.); d. Cyrilka Cave (the Moravskoslezské Beskydy Mts.). 

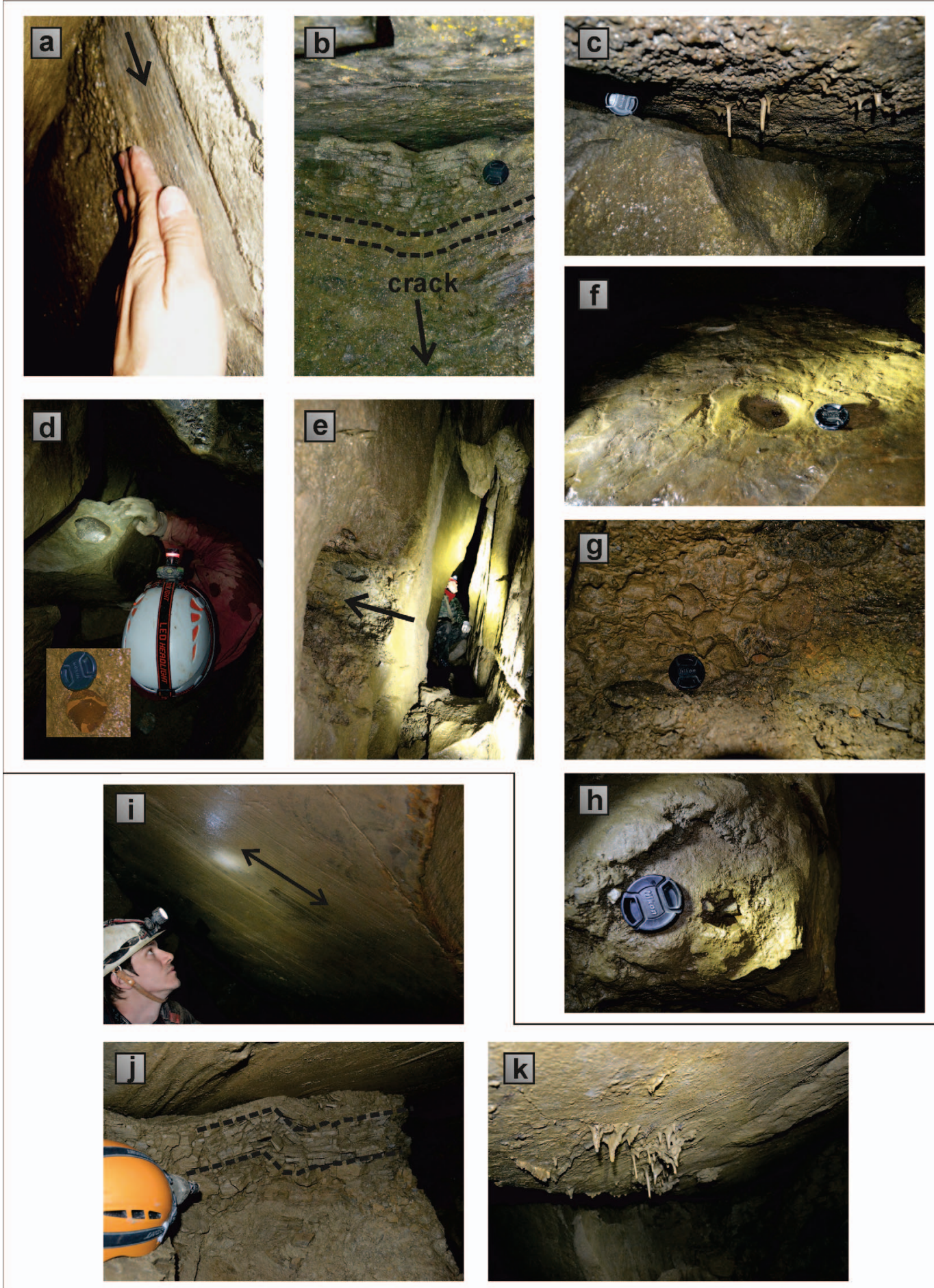

Figure 6. Micro-morphology of walls and ceilings of some crevice-type caves: a. Gravitationally caused striae; black arrow shows the direction of movement. b. Fold-like structure induced by the subsidence of shale layer into the gravitationally widened crack below the picture. c. Soda-straw-like stalactites. d. Ironstone balls. e. Holes from eroded coarse-grained layer sections. f. Tool marks (small-scale impact craters in the top of bed). g. Erosional surface after fallen out clasts. $h$. Holes in the solid rock due to dripping water. i. Consequent slickensides on the bottom of bed. j. Gravitationally induced fold. k. Soda-straw-like stalactites with mud content. a. Na Girové I Cave (the Jablunkovské mezihoří highland); b. Kněhyňská Cave (the Moravskoslezské Beskydy Mts.). c. d. inset, e., f., g., h. Cyrilka Cave (the Moravskosleszké Beskydy Mts.). d. Velká Ondrášova Cave (the Moravskoslezské Beskydy Mts.). i., Wiślańska Cave (the Beskid Śląski Mts., Poland, outside the study region); j., k. Pod Spišskou Cave (the Levočské vrchy Mts. Slovakia, outside the study region). 
Recent gravitational processes, such as rock collapses, caused the formation of fresh erosive surfaces and striae on the walls (length: $\sim 10 \mathrm{~cm}$; Fig. 6a). The plastic siltstones and claystones are occasionally gravitationally folded. This arises either from the sinking of sandstone beds up to several meters thick into the thin (up to $0.2 \mathrm{~m}$ ), plastic shale layers that are then pushed away and folded, or from subsidence of the shale layers into the gravitationally widened cracks (Fig. 6b).

Some parts of caves are modified by mechanical and chemical erosion. Due to presence of a variety of compositions of the beds in sedimentary flysch deposits, the weathering of exposed rocks within the passages is irregular. This is visible in the cave walls, where some sequences of beds, or only some sections, erode faster than others. This is especially true for the conglomerate or coarse-grained sandstone layers (Fig. 4d). In the walls, there are holes with erosion surfaces, formed from eroded coarse-grained layer sections (Fig. 6e,g) or intraclasts. The erosion sporadically exposes ferrolites, such as ironstone balls (Fig. 6d) or limestones and exotic blocks. Holes around 2 or $3 \mathrm{~cm}$ in diameter produced by dripping water are formed in the unconsolidated sediments and in rigid rock (Fig. 6h).

The solid walls are covered by thin $(\sim 0.1 \mathrm{~mm})$ layers of clayey mud that originate from the weathered siltstones and claystones. On well-preserved walls, this mud is sometimes formed into a small mud flowstones. Clayey mud, in conjunction with the calcareous cement from the sandstones, can form small sinter films or fragile soda-straw-like stalactites (length: $\sim 1$ to $10 \mathrm{~cm}$; Fig. $6 \mathrm{c}$ ) that have been described from four places within two caves in the study area (Wagner et al., 1990). Mineral iron coatings occasionally, though rarely, cover the walls.

\section{Discussion}

In contrast with karst caves, which are formed in connection with the slope movement evolution under the influence of karst dissolution (Gutiérrez et al., 2014), the crevice-type caves are products of gravitational processes without any dissolution.

Although the CTCs occur in various types of rocks, the examples in flysch sediments have many peculiarities. In the sense of the overall horizontal arrangement of the passages, their organization is controlled by the gravitational development of the landslide body. The formation of cave passages between blocks is conditioned by the discontinuities in the rock mass, lithological boundaries and bedding planes, while the directions of passages typically follow faults and joints. The gravitational processes tend to create passages typically parallel to the strike of the slope (Figs. 2 and 3). This arrangement has been observed at many other crevice-cave sites (Wagner et al., 1990; Demek and Kopecký, 1999; Margielewski and Urban, 2003; Majerníčková et al., 2005; Margielewski et al., 2007) and is caused by the lithological properties of rocks, tectonics, and morphometry of relief. The passages can also form parallel to the sloping ridge, as in the case of the Diabla Dziura w Bukowcu Cave (Polish Outer Carpathians; Margielewski and Urban, 2004).

Recent measurements show that the dilatation rate of the joints reaches $\sim 0.01 \mathrm{~mm} /$ year (Petro et al., 2011; Klimeš et al., 2012). Baroň et al. (2003) measured dilatation rates as high as 0.01 to $1 \mathrm{~mm} / \mathrm{month}$. Although the movements within the crevices are measurable, we still do not know whether the caves were formed by slow movements or during sudden short events, such as catastrophic landslides. Apparently, the regular network of sub-parallel passages is established during the progressive movement of particular rock blocks, but sudden movement cannot be excluded.

Along with the continuous release of the massif, the joints that are diagonal and perpendicular to the slope are also widened. The zone of joint widening is often laterally limited by the strike-slip faults (Figs. 2 and 3). Within the landslide body, the sliding movements and release of rocks are unevenly distributed. Recently measured vertical and horizontal rotations of the rock blocks (Petro et al., 2011), together with the uneven movements within the bulk of the landslide body, cause the irregular opening of the passages that is typical for most of the caves. This long-lasting evolution leads to the formation of the fan-like arrangement of the passages observed in plan view (Figs. 2c and 3d). A similar arrangement may develop when the widening of joints occurs in more than one direction; these directions may intersect to form the resulting arrangement. The fanlike feature is recognized at many other crevice-cave sites (Margielewski and Urban, 2004; Majerníčková et al., 2005; Margielewski et al., 2007; Szura, 2010; Lenart et al., 2014). In the case of the largest CTCs, there can be more than one fan-like zone compounded and connected together (Margielewski et al., 2007).

The cave passage network is limited and directed by the lithological boundaries (bedding planes) and joints. Along these discontinuities, the vertical levels are typically staircase-shifted (Fig. 3e). This shifting is known from other localities in the Polish and Slovak flysch Carpathians (Margielewski and Urban, 2003, 2004; Imrich et al., 2007). Particular levels usually show small and narrow connections (Fig. 3b). According to the main gravitational processes forming the cave, the width of the passages can change significantly from level to level. Although the lowermost passages are usually very narrow and the uppermost passages are wide, there are exceptions, where the widest passages are formed at greater depth (Imrich et al., 2007; Lenart et al., 2014). This might be caused by the character of the movements and also by the lithology. In the case of horizontally fan-like arranged passages ordered at several levels, the innermost rock blocks, which are wedged between the passages of the fan, typically have subsided into the space left by the gravitational release of the massif. This feature is also manifested in the vertical cross-section (Fig. 3f; Lenart 
et al., 2014). At the cross-section along the strike of the slope, the levels are not strictly horizontal along the profile. The benches of the passages often descend or ascend into the massif (Margielewski and Urban, 2004; Margielewski et al., 2007).

Regarding the morphology of the passages, the A, V, or $\mathrm{H}$ letter shape of the cross-sections is also typical for CTCs described from other localities (Self, 1985; Margielewski and Urban, 2004; Majerníčková et al., 2005). The specific shape is a result of the particular movement of two adjacent rock blocks (Lenart et al., 2014). The walls are usually vertically dissected by the particular beds, but they may also be flat, formed in a single thick bed (e.g., Imrich et al., 2007), or even curved (e.g., Margielewski and Urban, 2003).

Although the CTCs are not as rich in microforms as the classic karst caves, such features can be found at many cave localities. The most common microforms are Riedel shear structures on the walls. More unusual are hackle marks (ribbed or fringe structures), which are also known from other CTCs (e.g., Margielewski and Urban, 2004). I registered the pinnate structures in the Jaskyňa Pod Spišskou, in the Levočské vrchy Mts., Inner Flysch Carpathians, Slovakia, where the tectonically predisposed slickensides and fault surfaces along the fault zones occur on the exposed walls. In the Jaskinia Wiślańska, in the Beskid Śląski Mts., Poland, these slickensides also occur on the exposed lower bedding planes (Fig. 6i,) and thus, might be gravitationally predisposed. Margielewski et al. (2008) described spectacular gravitationally induced folds in the plastic shale layers from the Jaskinia Miecharska, in the Beskid Ślaski Mts., Poland. Gravitationally induced folds, as well as holes formed from eroded intraclasts, groove casts, and small soda-straw-like stalactites up to 10 to $12 \mathrm{~cm}$ in length (Imrich et al., 2007, Majerníčková et al., 2005; Fig. 6k) are known from the Jaskyňa Pod Spišskou, in the Levočské vrchy Mts., Inner Flysch Carpathians, Slovakia (Fig. 6j). Those stalactites are the most similar to those observed in this study.

Various types of other speleothems (stalactites, helictites, draperies, flowstone sheetings, moonmilk, crusts, microstromatolites, mud flowstones, etc.) are described from the Polish part of the Flysch Carpathians (Urban et al., 2007; Margielewski et al., 2008; Gradziński et al., 2010). Margielewski and Urban (2004) describe the iron mineral coatings on the exposed walls. Other speleothems described by Urban et al. (2007) include small calcite stalactities, moonmilk, and gypsum-calcite crusts or stalactites formed by amorphous substances with the participation of silica. Gradziński et al. (2010) describe the role of trapping and binding of siliciclastic detrital particles in microstromatolites by bacteria.

Majerníčková et al. (2005) found the carbonized remains of plants in the rocks forming the walls. Margielewski et al. (2008) describe various fluvial forms, such as bedforms, sandy mud sediments and ferruginous coatings in the streambed, from the Jaskinia Miecharska cave, the Beskid Śląski Mts., Poland.

\section{Conclusions}

Some of the observations concerning crevice-type caves in flysch deposits have been published earlier by previous scholars. This paper is a recapitulation of these observations in the Czech portion of the Outer Flysch Carpathians.

Although the crevice-type caves seem to be composed of chaotically organized underground passages of free space between rock blocks, the results of investigations suggest certain rules in the resulting arrangement, composition, and geometry of the passages. I investigated crevice-type caves in the area of Czech Outer Carpathians from the morphological point of view. According to the results, the main passages are typically parallel to each other and to the strike of the slope. The passages of the large caves are typically fan-like arranged due to an intersection of joint sets or to the nonuniform gravitational movement of the landslide body, where one side is opened more than the other. The passages become more undisrupted and narrow toward the tip of the fan.

Vertically, the passages are organized into levels, strictly governed by lithology, and connected together by elongated, but narrow, openings. Due to the lithological conditions within the massif, these levels can be typically staircase shifted. Toward the ground surface, there is usually detectable growth of the breakage of the massif and the amount of displacement of joints increases; the uppermost levels are often formed among open rock blocks. The gradual opening of the uppermost level may lead to the deformation of superficial terrain by trenches or sinkholes. The terrain above the caves may also be flat, which is evidence of the gravitational widening of the caves from within the massif. In the large caves, the arrangement of the levels is chaotic due to subsided rock blocks.

In cross-section, the passages are $\mathrm{A}, \mathrm{V}$, or $\mathrm{H}$ letter shaped, according to the type of gravitational movement leading to their development. The exposed rock surfaces are sometimes marked by various micro-morphological features originating from the sedimentary structures, tectonics, gravitational processes, and mechanical and chemical weathering processes.

Although the crevice-type caves are not as actively studied as karst caves, they represent a specific, and often unexpectedly frequent, phenomenon in terrain affected by slope deformations. The investigations show that the evolution of crevicetype caves is controlled by a true landslide behavior. Finally, this behavior drives the resulting morphology of the caves.

\section{ACKNOWLEDGEMENTS}

The research was co-funded by a financial subsidy from the Support for science and research in Moravian-Silesian Region 2014 program provided by the Moravian-Silesian Region. Thanks are extended to Michal Břežný, Jitka Hanzelková, Martin Kašing, Martin Kotouč and Václav 
Škarpich for their assistance during fieldwork and to Tomáš Pánek for his suggestive comments. I would also like to thank Elsevier Language Editing Services for English style revision and reviewers and editor for inspiring comments. Photo $\mathrm{c}$ in Figure 4 provided by O. Lenart, and photo $\mathrm{f}$ in Figure 4 provided by J. Wagner. Photo a in Figure 5 and photo d in Figure 6 provided by V. Škarpich.

\section{REFERENCES}

Baroň, I., Cílek, V., and Melichar, R., 2003, Pseudokrasové jeskyně jako indikátory svahových pohybů [Pseudokarst caves as indicators of slope movements], in Slobodnik, M., and Losos, Z, eds, Geologické Výzkumy na Moravě a ve Slezsku v roce 2002: Brno, Masaryk University, p. 84-87.

Bella, P., and Gaál, L., 2013, Genetic types of non-solution caves, in Filippi, M., Bosák, P., eds., Proceedings 16th International Congress of Speleology: Brno, Czech Speleological Society: v. 3, p. 237-242.

Demek, J., and Kopecký, J., 1999, Geomorfologické poměry okolí Ledových slují v Národním parku Podyjí [Geomorphology of the surroundings of ice caves in the Podyji National Park], in Saudek, K, ed., Pseudokrasový sborník: Praha, Česká speleologická společnost, p. 11-22.

Finlayson, B., 1986, The formation of caves in granite, in Peterson, K., and Sweeting, M.M., eds., New Directions in Karst: Proceedings of the Anglo-French Karst Symposium (September 1983): Norwich, Geo Books, p. 333-347.

Gaál, L., and Gaál, J., 1995, Vznik jaskyýn̆ svahovyými pohybmi blokoveého typu na priéklade Pohanskeého vrchu (Cerová vrchovina) [The formation of caves by the structural slope movements on example of the Pohanský hrad site (the Cerová vrchovina highland), Slovenský kras], v. 31, p. 17-34

Gradziński, M., Chmiel, M.J., Lewandowska, A., and Michalska-Kasperkiewicz, B., 2010, Siliciclastic microstromatolites in a sandstone cave: Role of trapping and binding of detrital particles in formation of cave deposits, Annales Societatis Geologorum Poloniae, v. 80, p. 303-314.

Gutiérrez, F., Parise, M., De Weale, J., and Jourde, H., 2014, A review on natural and human-induced geohazards and impacts in karst, Earth-Science Reviews, v. 138, p. 61-88. doi:10.1016/j.earscirev.2014. 08.002

Heeb, B., 2008, Paperless caving - An electronic cave surveying system. La topo sans papier - un système électronique de topographie: Proceedings of the IV European Speleological Congress, Vercors: p. 130-133.

Hutchinson, J.N., 1988, General report: Morphological and geotechnical parameters of landslides in relation to geology and hydrogeology, in Bonnard, C., ed., Proceedings, Fifth International Symposium on Landslides: Rotterdam,Balkema, p. 3-35.

Imrich, P., Kováćik, M., Bóna, J., and Majernícková, F., 2007, Geological control of the gravitational processes in The Spišská Hill pseudokarst region (Levočské vrchy Mts., Slovakia), Nature Conservation, v. 63, p. $47-55$.

Klimeš, J., Rowberry, M.D., Blahůt, J., Briestenský, M., Hartwich, F., Košlák, B., Rybáŕ, J., Stemberk, J., and Štěpanč́ková, P., 2012, The monitoring of slow-moving landslides and assessment of stabilisation measures using an optical-mechanical crack gauge, Landslides, v. 9, no. 3, p. 407-415, doi:10.1007/s10346-011-0306-4.

Krejǎ, O., Baroň, I., Bíl, M., Hubatka, F., Jurová, Z., and Kirchner, K., 2002, Slope movements in the Flysch Carpathians of eastern Czech Republic triggered by extreme rainfalls in 1997: A case study, Physics and Chemistry of the Earth, v. 27, p. 1567-1576, doi:10.1016/S14747065(02)00178-X.

Krejă, O., Hubatka, F., and Švancara, J., 2004, Gravitational spreading of the elevated mountain ridges in the Moravian-Silesian Beskids, Acta Geodynamica et Geomaterialia, v. 135, p. 97-109.

Lenart, J., Pánek, T., and Dušek, R., 2014, Genesis, types and evolution of crevice-type caves in the Flysch Belt of the Western Carpathians (Czech Republic), Geomorphology, v. 204, p. 459-476, doi:10.1016/j. geomorph.2013.08.025.

Majernícková, F., Majernícková, G., and Imrich, P., 2005, The Levočské vrchy mountains - pseudokarst paradise, in Hochmuth, Z., and Šmída, B., eds., Bulletin of the Slovak Speleological Society, special edition
2005: Liptovský Mikuláš, Slovenská Speleologická Spoločnost, p. $36-42$.

Margielewski,W., 2009, Problematyka osuwisk strukturalnych w Karpatach fliszowych $\mathrm{w}$ świetle zunifikowanych kryteriów klasyfikacji ruchów masowych - przegląd krytyczny [Problems of structural landslides in the Polish Flysch Carpathians in the light of unified criteria of the mass movement classifications-a critical review], Przegląd Geologiczny, v. 57, p. 905-917.

Margielewski, W., Szura, C., and Urban, J., 2008, Jaskinia Miecharska cave (Beskid Śląski Mts., Outer Carpathians) - The largest non-karst cave in the Flysch Carpathians, Zacisk: Biuletyn KTJ "Speleoklub" Bielsko-Biala, v. kwiecień 2008, p. 7-13.

Margielewski, W., and Urban, J., 2003, Crevice-type caves as initial forms of rock landslide development in the Flysch Carpathians, Geomorphology, v. 54, p. 325-338, doi:10.1016/S0169-555X(02)00375-6.

Margielewski, W., and Urban, J., 2004, Jaskinia szczelinowa Diabla Dziura w Bukowcu (Pogoórze Rożnowskie, Karpaty zewnętrzne) jako inicjalne stadium rozwoju głębokich osuwisk w Karpatach fliszowych [The crevice-type cave Diabla Dziura w Bukowcu (the Pogórze Rożnowskie hills, the Inner Carpathians) as initial stadium of deepseated landslides development in the flysch Carpathians], Przegląd Geologiczny [unlinked], v. 52, p. 1171-1178.

Margielewski, W., Urban, J., and Szura, C., 2007, Jaskinia Miecharska cave (Beskid Śląski Mts., Polish Outer Carpathians): Case study of a crevice-type cave developed on a sliding surface, Nature Conservation, v. 63 , p. $57-68$

Mastella, L., Zuchiewicz, W., Tokarski, A., Rubinkiewicz, J., Leonowicz, P., and Szczęsny, R., 1997, Application of joint analysis for palaeostress reconstructions in structurally complicated settings: Case study from Silesian Nappe, Outer Carpathians (Poland), Przegląd Geologiczny, v. 45, p. $1064-1066$.

Menč́k, E., Adamová, M., Dvořak, J., Dudek, A., Jetel. J., Jerková, A., Hanzliková, E., Houša, V., Peslová, H., Rybářová, L., Šmid, B., Šebesta, J., Tyřaček, K., and Vašiček, 1983, Geologie Moravskoslezských Beskyd a Podbeskydské pahorkatiny [Geology of the Moravskoslezské Beskydy, Mts. and Podbeskydská Pahorkatina Highland]: Praha, Ústřední Ústav Geologický, 304 p.

Pánek, T., and Duras, R., 2002, The morphotectonics of the eastern marginal slope of The Ropice-range (The Moravskoslezské Beskydy Mts.), Moravian Geographical Reports, v. 10, p. 20-27.

Pánek, T., Hradecký, J., Silhán, K., Smolková, V., and Altová, V., 2009, Time constraints for the evolution of a large slope collapse in karstified moun-tainous terrain of the southwestern Crimean Mountains, Ukraine: Geomorphology, v. 108, p. 171-181, doi:10.1016/j.geomorph. 2009.01.003.

Pánek, T., Margielewski, W., Tábořík, P., Urban, J., Hradecký, J., and Szura, C., 2010, Gravitationally induced caves and other discontinuities detected by 2D electrical resistivity tomography: Case studies from the Polish Flysch Carpathians, Geomorphology, v. 123, p. 165-180, doi:10. 1016/j.geomorph.2010.07.008

Pánek, T., Tábořík, P., Klimeš, J., Komárková, V., Hradecký, J., and Stastný, M., 2011, Deep-seated gravitational slope deformations in the highest parts of the Czech Flysch Carpathians: Evolutionary model based on kinematic analysis, electrical imaging and trenching, Geomorphology, v. 129, p. 92-112, doi:10.1016/j.geomorph.2011.01. 016.

Petro, L., Bóna, J., Kováăk, M., Fussgänger, E., Antonická, B., and Imrich, P., 2011, The Cave under the Spišská hill: Preliminary monitoring results of the block movements: Mineralia Slovaca, v. 43, p. $121-128$.

Rodet, J., 1983, Karst et littoral Bec de Caux (Seine Maritime, Normandie, France [Karst et littoral Bec de Caux (Seine Maritime, Normandie, France Coastal karst of Bec de Caux (Seine Maritime, Normandie, France)], Karstologia, no. 2, p. 23-32.

Self, C.A., 1985, Two gull caves from the Wiltshire/Avon border: Proceedings University of Bristol Speleological Society, v. 17, no. 2, p. 153-174.

Szura, C., 2010, The Jaskinia Wiślanska cave, cave plan, scale 1:200 (in Polish).

Urban, J., and Margielewski, W., 2013, Types of non-karst caves in Polish Outer Carpathians - historical review and perspectives, in Filippi, M., and Bosák, P., eds., Proceedings 16th International Congress of speleology, v. 3, p. 314-319.

Urban, J., Margielewski, W., Schejbal-Chwastek, M., Szura, C., 2007, Speleothems in some caves of the Beskidy Mts., Poland: Nature Conservation, v. 63, p. 109-117. 
Morphological patterns of CRevice-Type caves in Sedimentary rocks of the Outer Western Carpathians (Czech Republic)

Varnes, D.J., 1978, Slope movement types and processes, in Schuster, R.L., and Krizek, R.J., eds, Landslides: Analysis and Control: Transportation and Road Research Board, National Academy of Science, Washington D.C., Special Report 176, p. 11-33.

Vítek, J., 1983, Classification of pseudokarst forms in Czechoslovakia: International Journal of Speleology, v. 13, no. 1-4, p. 1-18.
Wagner, J., Demek, J., and Stráník, Z., 1990, Jeskynĕ Moravskoslezských Beskyd a okolí [Caves of the Moravskoslezské Beskydy Mts. and their surroundings]: Praha, Knihovna České speleologické společnosti, 127 p. Winkelhöfer, R., 1975, Die Höhlentypen im Sandstein der Sächsischen Schweiz [Types of caves in sandstones of the Sächsischen Schweiz highland], Der Höhlenforscher, v. 7, no. 3, p. 38-41. 